\title{
Spatial and Temporal Distribution and Environmental Factors Related to Larval Density An. Barbirostris and An. Subpictus in Bulukumba: an Approach to Industry 4.0
}

\author{
Iwan Suryadi ${ }^{*}$, Hasanuddin Ishak $^{2}$, Darmawansyah ${ }^{2}$ \\ ${ }^{1}$ Health and Company Hygiene and Occupational Safety, Medicine Faculty, Sebelas Maret University \\ ${ }^{2}$ Public Health Faculty, Hasanuddin University
}

\begin{abstract}
Characteristics of breeding site anopheles, sp supports the solidity of larvae An. barbirostris and An. subpictus . Purpose this study to analyzing Breeding place characteristics with the solidity of larvae An. barbirostris and An. subpictus and know spatially the distribution of Anopheles larvae in Bulukumba. The procedure with ecological survey design and the cross-sectional. Population and sample were breeding sites around the houses of malaria sufferers. Data were analyzed by the application of Statistical Product and Service Solution and Arc Gis 10.1. The spatial distribution shows that the positive Breeding place of Anopheles larvae is around malaria case houses at a distance of 500-1000 meters. Multivariate test on environmental characteristics showed that water temperature had the most influence on the density of $A n$. barbirostris larvae and salinity to the density of larvae An. subpictus. Environmental factors such as water temperature and salinity are factors that support the density of An larvae. barbirostris and An. subpictus . Spatial analysis of its relation to malaria is seen from the characteristics of the Breeding place also seen from rainfall, wind speed, and other climate variables so that predictive accuracy can be better. This is one form of development towards industry 4.0.
\end{abstract}

Keywords: Environmental Characteristics; Spatial Analysis and Distribution; An. Barbirostris; An. subpictus.

\section{Background}

Malaria is a disease that is transmitted through the most deadly insects. Half of the world's human population lives in areas affected by Malaria. There are around 1 million deaths per year, 250 million cases of clinical malaria every year and around 3.3 billion people are at risk of developing malaria [1].

The tropics are an ideal zone for infectious diseases through mosquito vectors. For all tropical regions around the world, Malaria is significant for human health because of the high level of morbidity and mortality. There were 216 million cases and 655,000 deaths were recorded annually according to the last census of 2013 with $81 \%$ of cases and $91 \%$ of deaths estimated to occur in Sahara Africa [2]. Many efforts have been made to reduce the risk of vector-borne diseases, especially in the tropics. However, these efforts need to be assessed in terms of practicality and ethical views [3].

Taking account of the spatial correlation structure in the data is important for "geographic transportability", i.e. when predicting malaria prevalence to unobserved locations [4].

The distribution of Anopheles vector species is influenced by environmental factors that support the life of the vector Anopheles sp showed that environmental variables affected the density of Anopheles larvae in several regions of Ethiopia. Furthermore, Mereta's research showed the presence of potential Breeding place for living areas and breeding grounds for Anopheles sp. such as Marsh s, trenches, puddles, streams of water, footprints were found to be positive with the presence of Anopheles sp. larvae. which was then used as a reference to establish a malaria control program [5].

The Study of vector Anopheles in Bulukumba Regency found 6 species of Anopheles mosquitoes that have the possibility as dispersion vectors, and An. barbirostris and An. subpictus is confirmed to be the most potential vector for distributing malaria [6].

Research by Zhou et al. sees the correlation between the distance of the patient's house and the body of water. The water body in question includes Paddy fields, rivers, and trenches which are places for malaria breeding vector larvae. This concludes that people who live near water bodies have a greater risk of being infected with malaria [7].

An. barbirostris found in highland in Sukabumi means that spatial distribution can see the relationship of environmental factors with the prevalence of Anopheles vectors [8].

The use of the gis application and spatial analysis methods facilitate mapping malaria vector control

\footnotetext{
*Corresponding author: iwansuryadi@staff.uns.ac.id
} 
measures tailored to meet the specific needs of the field team and program supervisors and managers in helping malaria control programs and understanding the spatial distribution of a disease [9-11].

A number of malaria risk maps, at the country and regional level, have been produced by analyzing georeferenced prevalence data against environmental data to predict prevalence at localities where it was not recorded [12-13].

The aim is to determine Breeding place characteristics and spatial distribution with the solidity of larvae An. barbirostris and An. subpictus, the spatial distribution supports predictions of areas that are potentially endemic to malaria.

\section{Methods}

\subsection{Study Design}

Study design with ecological studies through a crosssectional approach. The spatial information system is used to create a map of the distribution of Anopheles from various types of breeding Breeding places. An barbirostris and An. subpictus. Mapping or spatial distribution is done using the map maker application. Coordinating the breeding Breeding place points of Anopheles larvae was carried out using the Garmin global positioning system (GPS), then processing breeding Breeding place coordinate data using a mapmaking application to provide an overview of the breeding area and point of breeding of An. barbirostris and An. subpictus in Bulukumba.

\subsection{Population, sample and Sample Criteria}

The population of all Anopheles mosquito breeding Breeding place in Bulukumba Regency. While the research sample is the Breeding place of Anopheles mosquitoes. The sampling procedure was carried out by purposive sampling with the criteria being at a range of 500-1000 meters near the house of the case and reachable by the researcher.

\subsection{Instruments}

The research instruments were pipettes, canisters, larvae food, net larvae, larvae containers, gutters, salt meters, $\mathrm{pH}$ meters, GPS, label paper, and stationery writing observation sheets.

\subsection{Data Collection Procedure}

Observation of larvae was observed for a breeding place, density, breeding place characteristics in the research area. High solidity. A survey method for WHO standard larvae, assessment procedure in the form of larvae:

1. Confirmation is done by scooping up a body of water, a small body of water is carried out 10 times while the body of water that spreads is carried out more than 10 times.
2. Make observations

3. Anopheles larvae if the position is parallel to the water surface

4. Larval density formula. Density $=$ (number of catches) / (number of catches of larvae)

5. To facilitate identification of larvae by nurturing then identified in the laboratory

\subsection{Analysis of Data}

Univariate analysis with tables and figures to determine the distribution of Anopheles larvae and Breeding place characteristics and bivariate and univariate analysis to see the effect and strength of relationships between variables.

The distribution and spatial analysis methods are then plotted with district maps and the arc buffer method to calculate feature points at a certain radius.

\section{Result}

\subsection{Spatial Analysis Cases with place breeding}

Fig. 1 shows the distribution of Anopheles larvae species in Bulukumba Regency. The distribution of larvae found in the developed Breeding place was as follows: in the Districts of Bulukumpa and Rilau Ale found $A n$. barbirostris larvae, An. vagus, An. indefinitus and An. hyrcanus, Ujung Bulu District An larvae were found. Barbirostris, and An. subpictus, Ujung Loe Subdistrict, An. barbirostris, An. subpictus, An.vagus and An.indefinitus, Bontobahari Subdistrict, An. subpictus and An.vagus, Bontotiro Subdistrict, An.vagus, and An.indefinitus were found.

Fig. 2 shows 103 breeding points examined in the study area of various types of Breeding place types viewed within a 1000 meter radius. Using spatial analysis with a buffer method that aims to describe Breeding place types either positive or negative that are within a 100-1000 meter radius of the case house.

The results of the analysis of the case buffer indicate that the positive Breeding place in Bulukumpa and Bontobahari Subdistricts is at a 500-meter radius so that there is a potential risk of transmission.

An. barbirostris tends to be around the patient's home in that radius. Similarly Anububictus in Kec. Bontobahari. For a radius above 0-1000 meters, Anopheles positive place breeding is found

\subsection{Bivariate and Multivariate Analysis}

Table 1 shows the characteristics of the physical environment An. barbirostris and An. subpictus, An. barbirotris is dominantly found in paddy fields, the water temperature ranges from $20-300 \mathrm{C}$, likes a permanent breeding site and likes the intensity of the sun. The difference with An. subpictus namely An. subpictus prefers a fishpond breeding site.

Table 2 looks at the characteristics of a biological environment of An. barbirostris and An. subpictus, An. 
barbirotris prefers water plant s such as grass and Paddy, rare shade plants and high density of water plants. It's different from An. subpictus which is more like the type of water plant in the form of moss and algae, with rare shade plants and high density of water plants.

Table 3 illustrates the characteristics of a chemical environment. An. barbirostris and An. subpictus where the difference is An. subpictus can still be found in areas with fairly high salinity compared to An. barbirostris. For $\mathrm{pH}$ and turbidity An. barbirostris and An. subpictus likes pH 6-9 and likes cloudy water.

Table 1. Characteristics of the component of the physical environment breeding place

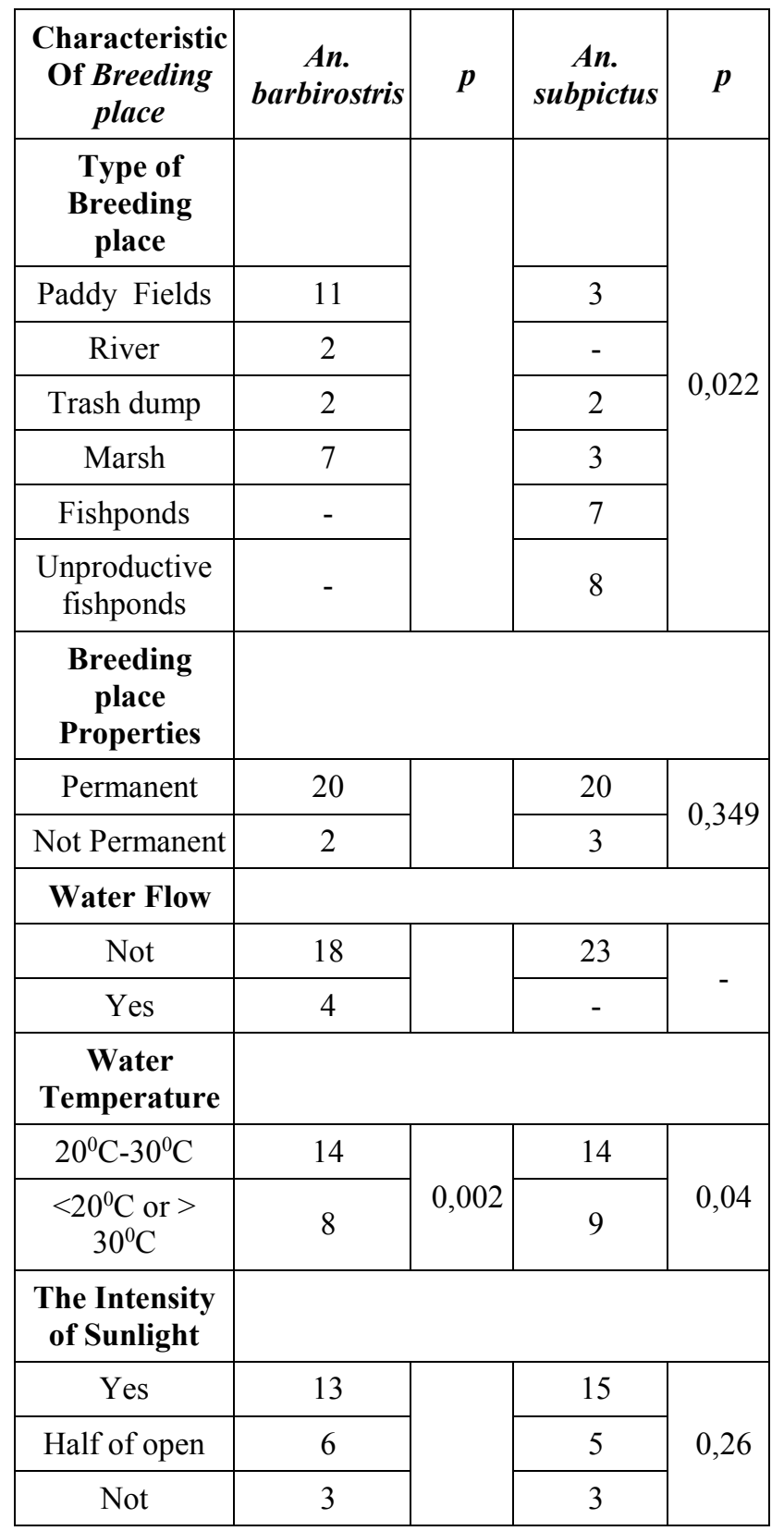

Table 2. characteristics of the component of the biological environment breeding place

\begin{tabular}{|c|c|c|c|c|}
\hline $\begin{array}{l}\text { Water } \\
\text { Plant }\end{array}$ & $\begin{array}{c}\text { An. } \\
\text { barbirostris }\end{array}$ & $p$ & $\begin{array}{c}\text { An. } \\
\text { subpictus }\end{array}$ & $p$ \\
\hline Yes & 18 & \multirow{2}{*}{0,042} & 20 & \multirow{2}{*}{0,023} \\
\hline Not & 4 & & 3 & \\
\hline \multicolumn{5}{|l|}{$\begin{array}{l}\text { Type of } \\
\text { Water }\end{array}$} \\
\hline Moss & 4 & & 14 & \multirow[b]{2}{*}{0,499} \\
\hline $\begin{array}{l}\text { Enceng } \\
\text { Gondok }\end{array}$ & 1 & & - & \\
\hline Grass & 11 & & 3 & \\
\hline Paddy & 5 & & 2 & \\
\hline $\begin{array}{c}\text { Water } \\
\text { spinach }\end{array}$ & - & & 1 & \\
\hline Negative & 1 & & 3 & \\
\hline \multicolumn{5}{|l|}{$\begin{array}{l}\text { Plants } \\
\text { Around }\end{array}$} \\
\hline Grass & 15 & & 9 & \multirow{4}{*}{0,844} \\
\hline Shrubs & 3 & & 3 & \\
\hline Forest & 3 & & 10 & \\
\hline Negative & 1 & & 1 & \\
\hline \multicolumn{5}{|l|}{$\begin{array}{l}\text { Shade } \\
\text { plants }\end{array}$} \\
\hline Negative & 10 & & 4 & \multirow{3}{*}{0,863} \\
\hline Rarely & 3 & & 6 & \\
\hline Crowded & 9 & & 13 & \\
\hline \multicolumn{5}{|l|}{$\begin{array}{c}\text { The density } \\
\text { of water } \\
\text { plant }\end{array}$} \\
\hline Negative & 5 & & 4 & \multirow{3}{*}{0,031} \\
\hline Rarely & 9 & & 6 & \\
\hline Crowded & 8 & & 13 & \\
\hline \multicolumn{5}{|l|}{ Predator } \\
\hline Positive & 3 & & 9 & \multirow{2}{*}{0,345} \\
\hline Negative & 19 & & 14 & \\
\hline \multicolumn{5}{|l|}{$\begin{array}{l}\text { Type of } \\
\text { Predator }\end{array}$} \\
\hline $\begin{array}{l}\text { Fish and } \\
\text { another } \\
\text { predator }\end{array}$ & 3 & & 9 & \multirow[t]{2}{*}{0,345} \\
\hline Negative & 19 & & 14 & \\
\hline
\end{tabular}


Table 3. Characteristics of the component of the chemical Environment breeding place

\begin{tabular}{|c|c|c|c|c|}
\hline pH & $\begin{array}{c}\text { An. } \\
\text { barbirostris }\end{array}$ & $P$ & $\begin{array}{c}\text { An. } \\
\text { subpictus }\end{array}$ & $P$ \\
\hline $6-9$ & 22 & & 18 & \\
\hline$<6$ atau $>9$ & - & & 5 &, 001 \\
\hline Salinity & & & & \\
\hline $0-0,25$ & 21 & \multirow{3}{*}{0,039} & 15 & \multirow{3}{*}{0,008} \\
\hline $0,26-0,5$ & 1 & & 6 & \\
\hline$>0,5$ & 0 & & 2 & \\
\hline \multicolumn{5}{|l|}{ Turbidity } \\
\hline Clear & 6 & & 5 & \multirow{2}{*}{0,370} \\
\hline Turbid & 16 & & 18 & \\
\hline
\end{tabular}

Table 4. Influence of environmental variables on the density of larvae of anopheles barbirostris and anopheles subpictus

\begin{tabular}{|l|l|l|}
\hline Variabel & An. barbirostris & An. subpictus \\
\hline Water & $P=0,002$ & $P=0,04$ \\
temperature & $\mathrm{R}=0,624$ & $\mathrm{r}=0,857$ \\
\hline Water plant & $\mathrm{P}=0,042$ & $P=0,023$ \\
& $\mathrm{R}=0,437$ & $\mathrm{r}=0,473$ \\
\hline $\begin{array}{l}\text { Type of Breeding } \\
\text { place }\end{array}$ & - & $\mathrm{P}=0,022$ \\
\hline $\begin{array}{l}\text { Density of water } \\
\text { plant }\end{array}$ & - & $\mathrm{r}=0,921$ \\
\hline Salinity & $\mathrm{P}=0,039$ & $\mathrm{P}=0,031$ \\
& $\mathrm{R}=0,443$ & $\mathrm{r}=-0,450$ \\
\hline pH & - & $\mathrm{r}=0,008$ \\
& & $P=0,0010$ \\
\hline
\end{tabular}

Description $=$ sign $(-)$ shows variables that have no influence.

Table 5. Species of anopheles in Bulukumba.

\begin{tabular}{|l|c|c|}
\hline $\begin{array}{l}\text { Species of } \\
\text { Anopheles }\end{array}$ & $\mathbf{n}$ & $\%$ \\
\hline An. barbirostris & 22 & 21,4 \\
\hline An. subpictus & 23 & 22,3 \\
\hline An. vagus & 12 & 11,7 \\
\hline An. Hyrcanus & 4 & 3,9 \\
\hline An. Indefinitus & 3 & 2,9 \\
\hline Negatif & 39 & 37,9 \\
\hline Total & 103 & 100 \\
\hline
\end{tabular}

Table 6. variable that has an influence on larva density An. Barbirostris

\begin{tabular}{|l|l|l|l|l|}
\hline Variable & B & Koefisien $\boldsymbol{p}$ & $\boldsymbol{p}$ & $\boldsymbol{R}^{\mathbf{2}}$ \\
\hline $\begin{array}{l}\text { Water } \\
\text { temperature } \\
\text { (constanta) }\end{array}$ & 0,500 & 0,624 & 0,002 & 0,358 \\
\hline Water plant & & & 0,886 & \\
\hline Salinity & & & 0,960 & \\
\hline
\end{tabular}

Table 7. Variable that has an influence on larva density An. Subpictus

\begin{tabular}{|l|l|l|l|l|}
\hline Variable & B & Koefisien $\boldsymbol{\beta}$ & $\boldsymbol{p}$ & $\boldsymbol{R}^{2}$ \\
\hline $\begin{array}{l}\text { Water } \\
\text { temperature } \\
\text { (Constanta) }\end{array}$ & & 0,121 & \\
\hline Water plant & & & 0,658 & \\
\hline Salinity & & & 0,059 & \\
\hline pH & 0,283 & 0,576 & 0,001 & 0,463 \\
\hline $\begin{array}{l}\text { Type of } \\
\text { Breeding } \\
\text { place }\end{array}$ & & &, 0572 & \\
\hline $\begin{array}{l}\text { Density of } \\
\text { water plant }\end{array}$ & & & 0,075 & \\
\hline
\end{tabular}

Table 4 shows the effect of environmental variables on An larvae. barbirostris and An. subpictus, where the water temperature, water plant, and salinity affect both Anopheles larvae, while the type of breeding site influences An larvae. Subpictus.

Table 5 shows the distribution of Anopheles species, the results of analysis with linear multivariate regression tests that water temperature is the most influential variable on larval density An. barbirostris. water temperature can predict the correlation density of 0.624 with the equation obtained with the density of larvae An. barbirostris $=0.500+0.500$ (water temperature) as shown in table 6 .

The results of the analysis used a linear multivariate regression test that $\mathrm{pH}$ was the most influential variable on larval density An, subpictus where $\mathrm{pH}$ can be predicted from larvae with a correlation of 0.653 . The value of $\mathrm{R} 2=0.399 \%$ means that the $\mathrm{pH}$ of water affects $39.9 \%$, where the rest is influenced by other variables as shown in table 7

Multivariate analysis is used to look at the most influential variable variables. The variables tested were water temperature, presence of water plant s and salinity for variables having a $p$-value of 0.05 and surrounding plants as well as predators of larvae for variables having p $>0.05$ but $<0.25$ as multicast test variables. 

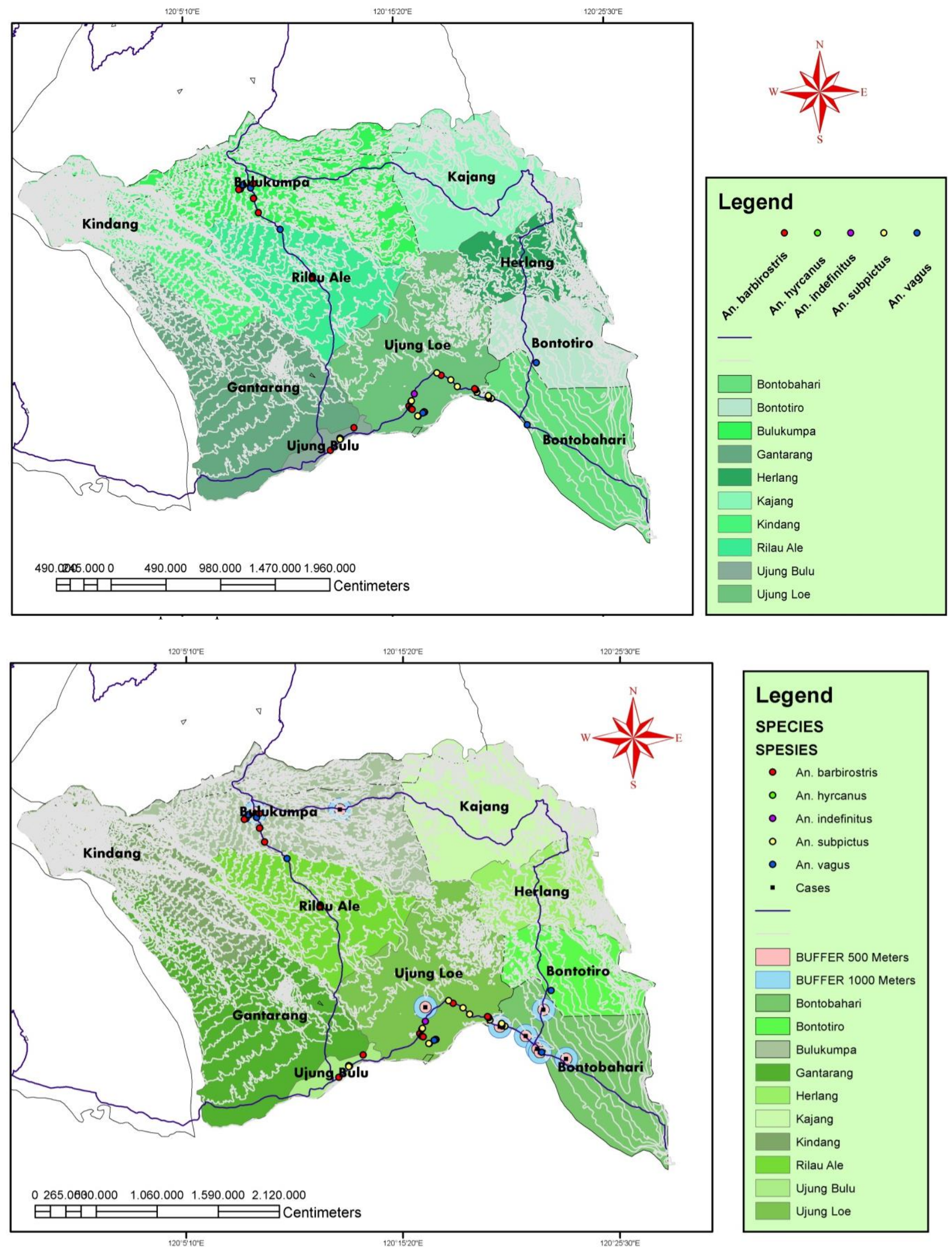

\begin{tabular}{|c|c|}
\hline \multicolumn{2}{|c|}{$\begin{array}{l}\text { Legend } \\
\text { SPECIES } \\
\text { SPESIES }\end{array}$} \\
\hline & An. barbirostris \\
\hline & An. hyrcanus \\
\hline & An. indefinitus \\
\hline$\circ$ & An. subpictus \\
\hline & An. vagus \\
\hline - & Cases \\
\hline & BUFFER 500 Meters \\
\hline & BUFFER 1000 Meters \\
\hline & Bontobahari \\
\hline & Bontotiro \\
\hline & Bulukumpa \\
\hline & Gantarang \\
\hline & Herlang \\
\hline & Kajang \\
\hline & Kindang \\
\hline & Rilau Ale \\
\hline & Ujung Bulu \\
\hline & Ujung Loe \\
\hline
\end{tabular}

Fig. 2. Map of Buffer Cases with Positive and Negative Breeding place in Bulukumba District. 


\section{Discussion}

\subsection{Spatial analysis of case houses and Breeding place for Anopheles larvae}

This study found 6 home points of cases, namely 2 points of case houses in Bulukumpa District, and 4 points in Bontobahari District. From the case of the house found case, researchers observed potential breeding Breeding place for Anopheles sp. Larvae. In this study, it was determined that the focused Breeding place was Breeding place within a 500-1000 meter radius from the house of malaria cases considering that the flight distance of mosquitoes was very limited in the range of 400 meters. The transmission of transmission has become widespread due to several influencing variables, one of which is population mobility [14].

As many as 18 potential larval Breeding place were observed in Ujung Bulu Sub-District from various Breeding place types, 5 potential larval Breeding place were observed in Bonto Tiro Sub-District from various potential Breeding places, 14 potential larval Breeding place from various Breeding place were observed in Bontobahari District, 19 potential larval Breeding place from various Breeding place in Bulukumpa District, 16 potential larval Breeding placefrom various Breeding place in Rilau Ale District and 31 potential larval Breeding place from various Breeding place in Ujung Loe District. The difference in the number of Breeding place points is influenced by the geographical conditions of the research location. Fig. 1 shows the distribution of positive Breeding place points for Anopheles sp. Larvae. in 5 research districts, it can be seen that the positive Breeding place of Anopheles sp. larvae. found in Ujung Bulu Subdistrict as many as 9 Breeding place s, 9 positive Breeding place in Bontobahari District, 2 positive Breeding places, and in Bonto Tiro District as many as 13 positive Breeding place points in Bulukumpa District, 10 positive Breeding place points in Rilau Ale District and 21 positive Breeding place points in Ujung Loe District is a positive Breeding place point. The most positive Breeding place type is paddy Breeding place type with 22 positive Breeding place and ponds with 15 positive Breeding place. Bulukumpa and Rilau Ale Subdistricts are the location of mountainous feet with land functions as agricultural land, Ujung Bulu Subdistrict, Ujung Loe and Bontobahari coastal areas where most of the land functions are used as locations for fisheries cultivation. So that many types of pond Breeding places are found compared to other districts.

The researchers found that in Bulukumpa and Bontobahari Subdistricts where after spatial analysis with the buffer method showed that at a distance of 500 meters from malaria patients there was a positive Breeding place for the breeding of Anopheles sp larvae so that at a distance there was a strong influence on the transmission of malaria spread. This is relevant to Rohani's research showing the correlation between the distance of malaria patients' houses with breeding a
Breeding place for Anopheles sp larvae as seen in the distance between case houses and positive Breeding places. in the study it was described that it is capable of flying at a distance of 100-500 meters. the ability of mosquitoes to fly correlates with the distance of breeding place with the patient's house so that it has the potential as a spread of malaria [15-17]

Malaria often forms a limited cluster/group, in a limited area, so that the three dimensions of transmission must occur in the area, the three dimensions in question are breeding, resting, and feeding [14].

The distribution of malaria cases is a case of imports and cases of displacement. The case of imports that occurred in Bulukumba District was a case of local residents carrying Plasmodium parasites from endemic and medical treatment in Bulukumba so that case reports in the area of origin.

The decline in cases in Bulukumba District was due to an intervention program from the Bulukumba Health Office working with assistance from the Global Fund to reduce the number of malaria cases such as distributing insecticide-treated bed nets in endemic subdistricts and high-risk groups such as pregnant and lactating women, entomology surveys to determine vectors and Plasmodium in mosquito bodies are routinely carried out and counseling by cadres of health centers under the auspices of the malaria department

Environmental interventions that are carried out related to the potential for transmission in Bulukumba Regency are by sowing larval predators on breeding Breeding places of paddy fields, ponds and Marsh $\mathrm{s}$ in endemic areas, stockpiling puddles that have the potential to provide anti-malarial drug Breeding place s.

Environmental control of Anopheles larvae can be done by environmental modification and environmental manipulation. Environmental modification such as hoarding mosquito breeding Breeding places that can be stockpiled, and manipulating the Breeding place environment by changing the original traits of the Anopheles mosquito breeding Breeding place.

Interventions conducted in rural and urban areas differ from each other. In the countryside, for example, controlling larvae with the use of insecticides such as temephos, in Paddy Breeding place and Marsh s can be sown with tin head fish seed as larval predators and maintain water flow in Paddy fields to reduce the risk of larvae.

Subsequent interventions can be carried out such as community participation by avoiding direct contact with mosquitoes such as the use of repellents, clothes and trousers and the use of wire mesh for homes close to breeding Breeding place such as in Bulukumpa District to avoid mosquitoes from entering the house.

\subsection{Spatial Analysis Larval Breeding place and species distribution of Anopheles sp. Larvae}

The type of Breeding place most commonly found in Bonto Tiro Sub-district is a puddle, the type of paddy fields found in Bulukumpa, Rilau Ale and Ujung Loe 
sub-districts while Breeding place in the form of ponds was found in Ujung Bulu and Bontobahari Districts.

The distribution of various types of Anopheles larvae shows that An. barbirostris is dominantly found in the Districts of Bulukumpa, Tanete and Ujung Loe with Breeding place types in the form of Paddy fields, rivers and Marsh s, while An. subpictus is dominantly found in Bontobahari and Ujung Loe Districts with Breeding place types in the form of ponds.

An. barbirostris and An. subpictus is an Anopheles vector in Bulukumba. entomology research shows $A n$. barbirostris altitude with habitat characteristics such as rice fields, forests, and rivers although it does not rule out the possibility that An. barbirostris can be found in coastal areas while An. subpictus is found in coastal areas with characteristics of place breeding such as ponds and swamps

An. barbirostris significant is found in highland areas, namely in the Districts of Bulukumpa and District of Rilau Ale and found in coastal areas, namely in Ujung Loe District.

Characteristics of An Breeding place. barbirostris such as Paddy fields, rivers, and Marsh s are found in the highlands in Bulukumpa and Rilau Ale Subdistricts and lowland areas such as Ujung Bulu and Ujung Loe Districts.

The difference in species of mosquitoes found is also related to the topography of a region, this can be seen in Figures 1 and 2 about the type of distribution of species in Kab. Bulukumba that An. barbirostris is found at elevations ranging from 8-448 $\mathrm{m}$ above sea level which indicates that An. barbirostris can be found in the lowlands and highlands.

This is in accordance with other studies that $A n$. barbirostris is found in highland areas, paddy fields, likes higher water temperatures, high $\mathrm{pH}$, shallow water depths and low salinity, and habitats are at an average longer distance than human habitation [18-19].

Research conducted by Ndoen et al, An. barbirostris in the East Nusa Tenggara region is more commonly found in coastal areas while in Central Java more is found in areas in the highlands and An. barbirostris can be found at an altitude of 10-800 meters above sea level. this shows that An. barbirostris can be found in altitude and coastal areas. The results of my research found something similar [20].

An. subjects Significant was found in coastal areas, namely in Bontobahari Subdistrict with Breeding place characteristics in the form of ponds and in Ujung Loe Subdistrict it was also found in Paddy fields at an altitude of 8-100 $\mathrm{m}$ above sea level. This is supported by research from Ndoen that An. subpictus is related to lagoons, brackish water, and mangrove forests that get direct sunlight 19].

An. subpictus in the Central Java region is found in hilly Paddy fields, while in the West-East region is dominantly found in coastal areas. This shows that the topography of the region has an influence on the spread of Anopheles sp. Species.

Topography has a strong correlation with the Anopheles mosquito where An. barbirostris can be found at any height while An. subpictus is predominantly found in coastal areas.

Environmental factors for a breeding Breeding place for An. barbirostris larvae which are the variable in this study as many as 12 independent variables divided into 3 sub-variables between the physical environmental factors which include water temperature, breed Breeding place type, water depth, sunlight intensity, water flow, and Breeding place characteristics. The second subvariable is biological environmental factors including Breeding place vegetation including the existence of vegetation, vegetation type, the density of water plant $\mathrm{s}$, shade plants and plants around the Breeding place of breeding sites. Then the predators of Anopheles spp larvae are included in the presence of predators and species of these predators. The third sub-variable is chemical environmental factors including $\mathrm{pH}$, salinity and turbidity of breeding Breeding place, while for the Anopheles spp larvae variable types are described descriptively.

This study shows that physical environmental factors have a correlation with the density of An larvae. barbirostris and chemical environmental factors have a correlation with the density of An. subpictus larvae. The spatial distribution shows that there is An. barbirostris found in highland and coastal areas while An. subpictus is found in coastal areas.

This study found that the research Breeding place was focused within a 500-1000 meter radius of the malaria case house with consideration of the very limited flight distance of mosquitoes in the 400-meter range. The positive Breeding place is within a 500-meter radius. So there is a potential risk of transmission.

An. barbirostris is commonly found in hilly and paddy fields, especially sub-district Bulukumpa, Bontobangun, Ujung Bulu, and Ujung Loe. While An. subpictus was found in the coastal areas, namely the Ujung Bulu sub-district, Ujung Loe and Bontobahari which are coastal areas. Bulukumpa and Bontobangun are altitude areas while Bontobahari, the tip of the feather and the tip of Loe are coastal areas. This shows that the topography of an area has an influence on the spread of Anopheles sp, according to a study by Ndoen [20].

The difference in the distribution of Anopheles place breeding seen from the topography of the area where $A n$. barbirostris can be found in coastal and highland areas while An. subpictus can only be found in coastal and coastal areas.[21].

The research used the spatial method to see the distribution of Anopheles and malaria is one method that is able to make predictions on areas that might be endemic so that they can be controlled early. Spatial analysis of its relation to malaria is seen from the characteristics of the Breeding place also seen from rainfall, wind speed, and other climate variables, This study was refined by $[30,31]$ by using a spatial model to predict the prevalence of malaria and other infectious diseases in unobserved locations using the Bayesian geostatistical spatial model and spatial correlations so that predictive accuracy can be better. This is one form of development towards industry 4.0. 


\subsection{Analysis of Environmental Characteristics of An.barbirostris and An Larvae Densities. subpictus}

Water temperature influences the density of An larvae. barbirostris and An. subpictus results of bivariate analysis and multivariate analysis that the water temperature has the strongest influence on the density of An larvae. barbirostris compared with other variables with water temperatures ranging between $21-31^{\circ} \mathrm{C}$. In accordance with a research by Christiansen et al the relationship of temperature to larval breeding shows that the temperature is optimal for the development of An larvae. gambiae between $23-31^{\circ} \mathrm{C}$ also supported by research by Ahmad $[22,16]$.

Water temperature affects the breeding of larvae. Anopheles mosquito larvae prefer high temperatures. That is why the type of Anopheles is more commonly found in the tropics. Water temperature also affects the hatching time of Anopheles eggs where higher water temperatures will accelerate the hatching time of eggs.

Research conducted by Moesa Soleimani et al showed a positive correlation between water temperatures in Breeding place with larval density, this shows that at high temperatures will reduce the presence of larval predators. In addition, an increase in temperature above $31{ }^{\circ} \mathrm{C}$ affects larval mortality [22, 23].

Water plants in breeding habitats play an important role in the presence of Anopheles larvae because water plants function as a place to rest mosquitoes at the surface of the water.

Algae and water plants that rot on the surface of the water that is widespread and get direct sunlight greatly affect the proliferation of larvae, because microfauna and microflora as larvae feed ingredients gather around many plants.

Plants or vegetation found at the research site for $A n$. barbirostris in the study area in the form of grass, Paddy, moss and water hyacinth. The presence of vegetation can cause an increase in larval density because it provides hiding places and food so that larvae can survive. Plants can be protective of larvae or shelter Breeding places that they are not directly exposed to sunlight which can cause an increase in water temperature and disturbance of predators which can reduce the number of mosquito larvae in breeding Breeding place [24].

$\mathrm{pH}$ is useful for respiration in the body of a mosquito, the $\mathrm{pH}$ that Anopheles likes varies but generally ranges from 6-9.

Research by [25] that An larvae. barbirostris likes sunlit water bodies, such as lagoons, ponds, slow running waterways, along river banks, and Paddy fields and vegetation-over Breeding place.

Other studies that support the characteristics of breeding sites of An. barbirostris, among others, is research on malaria vectors dominant in the Asia Pacific region showing that the Breeding place of An larvae. barbirostris has a low salinity type of brackish Breeding place, Marshs, artificial lakes, Paddy fields, irrigation canals and ponds $[26,27]$.
Salinity affects the density of An larvae. subpictus, so it has a significant correlation with the direction of the medium correlation. There is a strong correlation between salinity and the density of Anopheles larvae and different salinity levels in various breeding Breeding place types affect the density of An larvae. Subpictus [19-21].

The research conducted by Singh et al shows $A n$. subpictus prefers to breed in brackish water with water salinity between $0.004-0.734 \%$. In addition, the presence of water vegetation such as water hyacinth and algae is a good place for laying eggs $[28,29]$.

\section{Conclusion and Recommendations}

This study analyzed spatially based on the buffer map, indicating that houses in the vicinity of Breeding place within a 500-1000 meter radius in Bontobahari Subdistrict were set at a zone of the high risk of transmission. The physical environment characteristics of the temperature became the most influential variable on the density of An.barbirostris larvae. The characteristics of the physical environment of salinity were the most influential variables on the density of $A n$. subpictus larvae. The distribution of Anopheles larvae found in this study was An. An.vagus, An.hyrcanus and An. indefinitus. It is recommended that a collaboration between the Bulukumba District Health Office and the Public Works Service be carried out to improve the irrigation system, especially for a temporal Breeding place to cope with the breeding Breeding place of Anopheles sp. Larvae.

The research used the spatial method to see the distribution of anopheles and malaria is one method that is able to make predictions on areas that might be endemic so that they can be controlled early. Spatial analysis of its relation to malaria is seen from the characteristics of the Breeding place also seen from rainfall, wind speed, and other climate variables so that predictive accuracy can be better. This is one form of development towards industry 4.0

\section{References}

1. I. Khan A. Zeb, A. Prst. and Vectrs. J. 6(1), 90 (2013)

2. L. Gougna, M. Rakotondranary, S. Boyer, G. Lemperiere, J.S Deheck, D. Fontenille, Prst. and Vectrs J. 5(4) (2012)

3. Cailly, P.T. Bellenghien, P. Ezzano, D. Fontenille, C. Toty, A. Tran, Prst. and Vectrs. J. 4(4) (2011)

4. P Diggle, R Moyeed, B Rowlingson, M Thomson 51, 493-506 (2002)

5. M.E. Sinka, M.J. Bangs, S. Manguin, T Chareonviriyaphap, A.P. Patil, W.H. Temperley, P.W. Gething, I.R.F. Elyazar, C.W. Kabaria, R.E. Harbach, S.I. Hay, Prst and Vectrs J. 4(89), 76 (2011)

6. S.T. Mareta, D. Yewhalaw, P. Boets, A.H. Ahmad, L. Duchateau, N. SpeyBroeck, S.V.W. Legesse, 
L.D. Meester, P.L.M. Goethal, Journal Prsts. \& Vctr. 6, 1-6 (2013)

7. Asniar, H. Ishak, I. Wahid, Unhas Repository, 1-8 (2012)

8. Z. Shui-Shen, Z. Shao-Shen, W. Jian-Jun. Z. Xiang, H. Fang. L.Dong-Wei. X.Xian. Z. Hong-wei, Prst. and Vectrs. J, 5(106), 6 (2012)

9. C. Stoops, A.S. Rusmiarto, D.Susapto, A. Munif, H Andris, K.A Barbara, S. Sukowati, J. of Vetr. Eclgy. 34, 200-207 (2009)

10. Dongus, S.V. Mwakalinga, K. Kannady, M. Tanner, G. Killeen, Springer IV, 321-322 (2011)

11. A.A. Hanafi-Bojda, H. Vatandoosta, M.A. Oshaghia, Z. Charrahyb, A.A. Haghdoostc, G. Zamani, F. Abedi, M. Sedhagat, M. Soltani, M. Shahi, A. Raeshi, Act. Trpc. 122, 132-137 (2012)

12. H. Bojd, A.A.H Vatandoost, M.A. Oshaghi, Z. Charachy. A.A. Haghdoost, M.M. Sedaghat, F. Abedi, M Soltani, A. Raesi. J. of Vctr. Born Disease 49, 93-99 (2012)

13. I. Kleinschmidt, M. Bagayoko, G.P. Clarke, M. Craig, D.L. Sueur, Int. J. Epidemiol 29, 355-361 (2000)

14. H. Kassiri, H. Amani, Zjmrs. J. 14, 11-12 (2012)

15. Santjaka, Malaria Model Approach to Causality, Nuha Medika: Jakarta (2013)

16. R. Ahmad, W.N.W.M. Ali, Z.M. Noor, Z. Ismail, A.A. Hadi, M.N. Ibrahim, L.H. Lim, Malaria J. 10, $1(2011)$

17. R. Ahmad, WMA. W. Najdah, I. Zamree, A.H. Azhari. I.M. Noor. H. Rahimi, H.L. Lee, J. Trop. Mdcl. PH. 41, 1-10 (2010)

18. C. Stoops, A.Y.R. Gionar, Shinta, P. Sismadi, I.R.F. Elyazar, M.J. Bangs, S. Sukowati, J. of Mdcal. Entmlgy. 44, 1 (2008a)

19. C. Stoops A.Y. Gionar, Shinta, P. Sismadi, A. Rahmat, I.R.F. Elyazar, S. Sukowati, J. of Vetr. Eclgy. 33, 36-38 (2008b)

20. E. Ndoen, C. Wild, P. Dale, N. Sipe, M. Dale. Malaria J. 9, 4-9 (2010)

21. I. Suryadi, Breeding Place Characteristics with An. barbirostris Larva Density in Bulukumba, E3S Web Of Conference 73 (2018)

22. I. Suryadi, S. Rachmawati, Indian J. 9, 49-50 (2018)

23. C.C. Juct, P.E. Parham, A. Sadler, J.C. Koella, M.G. Basanez, J. Prste. \& Vctr. 7, 1-10 (2014)

24. M. Ahmadi, A.A.H. Soleimani, H. Bojd, M. Zare, R. Saffare, A.R. Mojahedi, F.P. Garbandi, J. of Pasific of Trop. Med. 7, 512-514 (2013)

25. R.R. Rahman, H. Ishak, E. Ibrahim, Repository of Unhas, 1-14 (2013)

26. I.R.F. Elyazar, M.E Sinka, P.W. Gething, S.N. Tarmidzi, A. Surya. R.K. Winarno, J.K. Baird, S.I. Hay, M.J. Bangs, Advcs is Prstolgy, Elsvier 83, 186189 (2013)

27. M.E. Sinka, M.J. Bangs, S. Manguin, T. Chareonviriyaphap, A.P. Patil, W.H. Temperley, P.W. Gething, I.R.F. Elyazar, C.W. Kabaria, R.E. Harbach, S.I. Hay, Prst. and Vectrs. J. 4(89), 76 (2011)

28. R.K. Singh, G. Kumar, P.K. Mittal, R.C. Dhiman, IJMR 1, 29-37 (2014)
29. P.J. Jude, R Ramasamy, S.N. Surendran, J. of Insct. Scienc. 14, 1-10 (2014)

30. M.H. Craig, B.L. Sharp, M.L.H. Mabaso, I. Kleinschmidt, IJOHG, 6(44), 1-15 (2007)

31. M.C. Wimberly, A.D. Baer, M.J. Yabsley, IJOHG 7(15), 1-14 (2008) 